International Journal of Civil Engineering and Technology (IJCIET)

Volume 11, Issue 9, September 2020, pp. 32-42, Article ID: IJCIET_11_09_003

Available online at https://iaeme.com/Home/issue/IJCIET?Volume=11\&Issue=9

ISSN Print: 0976-6308 and ISSN Online: 0976-6316

DOI: https://doi.org/10.34218/IJCIET.11.9.2020.003

\title{
REGULATORY BASELINE REPORTING: THE CASE FOR QUANTIFYING EXPECTED REGULATORY COSTS AND DELAYS IN A BASELINE REPORT - LESSONS IN CROWN UNFAIRNESS FROM AUSTRALIA
}

\author{
Arnold E. Dix \\ Barrister-at-Law (Victorian Bar), Australia; Associate Professor of Engineering, \\ Tokyo City University, Tokyo, Japan
}

\begin{abstract}
In all countries the Crown (the Sovereign or Government) is the source of all law, it creates all regulatory authorities and manages all privatised and corporatized entities that collectively generate the largest non-engineering risks for underground works projects - regulatory approvals and delays. The common international practice by the Crown of contractually transferring both ground and regulatory risks to successful bidders seriously jeopardises the sustainability of the underground works construction industry which is already suffering from low profit margins. This issue is especially obvious in Public Private Partnership style contracts or those which claim to be 'fair' but at the same time entrench major risk transfer of ground conditions and regulatory burdens away from the Crown. The regulatory risks are usually much larger than the ground risks. The Crown's practices often so unfair, that in certain circumstances, they are also likely unlawful under many countries legal systems. As well as possibly being unlawful these practices can also lead to a substantial reduction in bid competition. Project commercial packages are also becoming so large, and the unknown regulatory risks so great, that fewer companies have the ability or appetite to participate in a competitive process where the scale of the unquantified regulatory risks potentially jeopardises the survival of the company. It is suggested that regulatory risks should be the subject of a Regulatory Baseline Report $(R B R)$ in which the Crown defines the risks for the purposes of bidding and the future management of unexpected regulatory disturbances. Countries such as Australia should transition away from bespoke project by project contracts to more common forms of contract that embrace accountability by the Crown for risks uniquely within its control or influence, and thereby empower the Crown's delivery authorities to deliver their projects, encourage broad participation by the market and develop a culture of commercial fairness as is enjoyed in some developed countries.
\end{abstract}

Keywords: Contract; Fairness; Ground Risk; Crown; GBR; Sovereign; Risk; Law; RBR 
Regulatory Baseline Reporting: The Case for Quantifying Expected Regulatory Costs and Delays in a Baseline Report - Lessons in Crown Unfairness from Australia

Cite this Article: Arnold E. Dix, Regulatory Baseline Reporting: The Case for Quantifying Expected Regulatory Costs and Delays in a Baseline Report - Lessons in Crown Unfairness from Australia, International Journal of Civil Engineering and Technology, 11(9), 2020, pp. 32-42.

https://iaeme.com/Home/issue/IJCIET?Volume=11\&Issue=9

\section{INTRODUCTION}

The Crown is uniquely able to control a range of regulatory, cost and delay risks associated with its underground works projects. The Crown has duties of fairness when entering contracts for underground works and special Crown duties as a model litigant to, at all times, behave fairly. The practice which has emerged in some countries such as Australia is to transfer risks peculiarly under the control or directing influence of the Crown to the successful project bidders.

The practice of the Crown assigning these Crown controlled or directable risks to the Contractor without accountability under the contract can be unfair. Regulatory cost and delay risks stemming from the Crown's unique sphere of regulatory influence ultimately become costs of the project in terms of finance, delay and quality of outcome. It is unfair of the Crown not to be accountable for its own actions when procuring its own projects. It is unfair to have data rooms during commercial negotiations if the data contained within them cannot be relied upon.

Such simplistic and unfair contractual practices threaten the ability of governments to deliver the cost-effective infrastructure the world needs as we move towards the $22^{\text {nd }}$ century.

In Australia even after announcements of contractual policy reform directing Crown risks be retained by the Crown, neither the Crowns agencies nor their lawyers adjusted the practices to reflect the positive and entirely modern new Crown policy.[1]

“... Risks must be managed collaboratively including risks relating to utilities ... approvals and latent conditions, ... develop standard contractual risk sharing mechanisms ... manage and reduce utility-risks ... establish ... 'dispute avoidance' forums ..."

The issues seriousness is compounded by increasingly large project sizes that threaten to overwhelm the markets ability to accept the magnitude of the commercial risks. In Australia this risk to projects has been specifically identified.

'... do not put the contractors' overall viability at risk"'[2].

These contractual practices also cripple the ability of the Crowns own delivery authorities to optimise projects. Delivery authorities are restrained by the Crown who controls the ultimate form of the project contracts. Delivery authorities need the contractual tools to encourage innovation and project efficiencies. The Crowns delivery authorities are often constrained by contracts that do not promote any substantive deviation from reference designs with little or no latitude to deviate due to the regulatory consequences of any variation.

Delivery authorities are also constrained by the lack of certainty and accountability between other Crown agencies and corporatized entities under the effective control or influence of the Crown.

Unless there is a paradigm shift in Crown risk allocation future major underground works projects run the increased risk of escalating cost, disputes and delays. Even where innovative tools such as Geotechnical Baseline Reports (GBR) are utilised, the way they are drafted and their priority in the contract must be carefully drafted so that their adoption is not just a formality. It is likely that the real drivers for GBR adoption in some countries is to attract insurance by complying administratively with the requirements of the International 
Tunnelling Insurance Group's recommendations[3] and to attract foreign participants as bidders to projects.

Countries like Australia must modernise its contractual practices. The national fascination with bespoke contracts merely fuels a litigious and counter-productive project delivery cultures. Bespoke contracts are often grossly unfair, sometimes unlawful and divert limited resources from the engineering tasks. International organisations such as FIDIC, ICE, NEC, AFTES and ITA all point to the importance of fair risk allocation and a focus upon engineering as keys to delivering efficient and effective underground works.

The reform of underground works contractual practices is in the global interest. The approach in countries like Australia of allocating regulatory risk and ground risk almost entirely on the successful bidder negates any real appetite for innovation of reference designs, alternative solutions, value engineering, and thereby increases project cost, project risks and suresses the appetite of the market to enter into contracts at all.

\section{MODERN CONTRACTS}

When a government seeks bidders to build major underground works projects, it should be presumed that the project will be supported by all arms of government and that to the extent the government and its agencies frustrate the delivery of the project the contractors will not be penalised. This is because governments are uniquely placed to control regulatory risk and they should be held accountable for their own actions. Such responsibility strikes at the heart of the general duties of fairness of contracting parties and the specific duties of the Crown because it is the Crown.

When contracts are entered into for underground works, private rules are created that establish the rights and responsibilities between the parties. In legal theory the consequences of this rule making are profound. Historically the strengths of this ability of parties to a contract to set the rules for their future dealings is based upon the philosophical view that all parties to a contract freely enter the contract, are of equal bargaining position and fully informed.

In underground works contracts there is often no such equal bargaining position. In countries such as Australia bespoke and highly complex contracts are the norm, short and aggressive competitive bid processes the practice and governments typically utilise a 'take it or leave it' approach to negotiation over key contractual provisions. Agencies within the Crown's control and corporate entities within the Crown's influence are not required to commit to timeframes, regulatory controls, fees or charges in relation to a proposal. There is no schedule of likely costs in terms of fees or time. The regulatory framework remains at large and in substance unaccountable to the Crown's project. Data shared pre-bid in data rooms is on an "all care - no responsibility" basis - and time frames for proposals are almost always deficient given the scale and complexity of the projects.

The consequence of this aggressive contracting environment has likely contributed to the financial stress of many underground works companies around the world and in Australia[4] stressed projects and driven up the ultimate (post disputes) costs of infrastructure. For those companies that choose to engage in underground works the contractual environment in jurisdictions such as Australia the commercial environment is often aggressive, and claims based.

The emergence of a highly sophisticated claims-based contract management culture in the later part of $20^{\text {th }}$ century in countries such as Australia has driven the development of litigious contracting environments. A key feature of most underground works contracts in aggressively claims based and litigious projects is the substantial transfer of risks to the contractor of matters best known and controlled by the Crown. 
Regulatory Baseline Reporting: The Case for Quantifying Expected Regulatory Costs and Delays in a Baseline Report - Lessons in Crown Unfairness from Australia

From inappropriate ground risk allocation to just stepping away from assisting contractors secure a stable and reliable regulatory environment, the conduct of the Crown in countries such as Australia suggests that it either is incapable or has no interest in aggressively managing its own government agencies to help facilitate delivery of the projects it wants. Government projects should be supported by government. Government is best able to support its own projects by assuming the risk of its own authorities and agencies. Where governments choose to allocate these risks to a contractor there is a strong case that the Government should represent to the Contractor the likely time and cost burdens of complying with these regulatory requirements. Like ground conditions, they could be dealt with in a Regulatory Baseline Report that evidences the expected regulatory burdens and provides a mechanism to adjust the contract price and duration if the regulatory burdens are not as expected.

Such a mechanism would provide accountability to government for the conduct of its own agencies and authorities and allows contractors to more precisely price regulatory risk. Unlike ground risk, regulatory risk is peculiarly and entirely within the control of the Crown and such a mechanism would provide accountability to the Crown for the conduct of its agencies in delivering its own projects.

The Crown's regulatory authorities and the privatised entities that currently administer previous Crown assets and activities generate a large proportion of project risk and stifle opportunities for innovation and efficiency.

In the $21^{\text {st }}$ century, where the private sector is needed by government to deliver major underground infrastructure, the law should encourage the Crown to behave fairly. At its simplest, fair contracting by the Crown can be achieved by embracing modern contractual mechanisms for allocating risks associated with approvals, actions and expenses uniquely controlled by the Crown and its agencies and ground risks like those contained in the latest FIDIC Emerald Book.[5] At a broader level the issues raised by underground works disputes suggest that legislative intervention may be required to define what standards are expected of the Crown and its agents, such as Government Departments and regulatory authorities. For Crown projects it is reasonable to expect that all arms of government will act fairly and if they do not the burden for such unfair behaviour should fall back upon the Crown.

\section{HISTORICAL LEGAL CONTEXT}

Historically in the common law world contracts have changed to reflect the evolving economic and social circumstances of society.

In medieval society business was transacted at a local level, mostly free of complexity, upon a handshake and aimed at resolving disputes by compromise.

"There was a strong emphasis ... on the observance of equity as opposed to the strict letter of the law ... on an absence for formality in a contract ... " [6]

By the $17^{\text {th }}$ century the law had changed, and important contracts had to be evidenced in writing, and signed, for them to be enforced[7][8]There was a sense of fairness:

"... wherever a defendant is under a moral obligation, or is liable in conscience and equity to pay, that is a sufficient [reason] ..." [9]

The notion of "fairness" is central to countries of Civil Law heritage until this day. A party cannot set itself in contradiction to its previous conduct vis-à-vis another party if that latter party has acted in reasonable reliance on such conduct ("venire contra factum proprium"; "interdiction de se contredire au détriment d'autrui"). This principle is often entrenched in the Civil codes of Civil law countries.[10] 
In the $18^{\text {th }}$ century the notions of fairness being implied into contracts in the common law world fell out of favour.

The industrial revolution favoured concepts of parties entering contracts freely and thereby accepting the rules as agreed and written in the contract. The Courts were extremely reluctant to question the contract on the basis that it was unfair.[11]

"... You cannot exercise a discretion by merely considering what, as between the parties, would be fair to be done; what one person may consider fair, another person may consider very unfair; you must have some settled rule ..."

An error on the part of one party was no basis to set aside a contract unless it had been induced or contributed to by the conduct of the other party.[12]

In $19^{\text {th }}$ century Australia, State governments emerged as key entrepreneurs and investors. The Australian States are analogous to regions within the common law world such as Scottland, New Zealand, the States of the United States, Canada and Hong Kong. [13] [ooj]

The State agencies supported the State projects and all arms of the Crown contributed their considerable expertise and power to the delivery the projects. The private sector played an important but comparatively small role.

In the $21^{\text {st }}$ century the distinction between projects of the State and the private sector is blurred. Governments often no longer have the money or expertise to deliver major infrastructure alone. In Australia it is common practice through a range of contractual mechanisms for contractors to be delivering and operating infrastructure which would in the $19^{\text {th }}$ century have been entirely owned and operated by the State. The delivery of State infrastructure by the private sector is routinely vilified publicly by politicians despite the fact that the State is incapable and unwilling to construct the projects themselves. The partnership between public and private sectors demands trust.

The private sector legitimately expects to make a profit when it delivers projects as contracted. It is entirely unfair that the actions of agents of the Crown can burden a contractor with unanticipated costs and delays without any accountability. A Regulatory Baseline Report would provide more certainty around regulatory risks. But, like a GBR it would have to be drafted in good faith in order to maintain commercial tension and appropriate conduct by all parties.

It is in societies interest that underground works infrastructure be built and operated most efficiently. The scale of these endeavours is so large that inefficiencies can have GDP impacting consequences and create debts and costs that burden multiple generations of citizens.[14]

In recent decades many governments have imposed specific contractual terms that entirely place ground condition risk (sovereign risk) and regulatory/approvals risk with the Contractors and then invite the market to enter a fierce commercial battle in which the lowest bidding Contractor assumes these ground and regulatory sovereign risks. Financiers are advantaged by such risk apportionment but rarely is this motivation for such practices acknowledged or discussed.

Governments, as sovereigns, can change the regulatory environment and even legislate to avoid contractual liability.[15] The successful bidders and Contractors have no such power and little effective ability to alter the terms of their agreement with the Crown.

Given the size and cash flow burdens of these underground works projects, it is to be expected that treasuries require certainty of price. Unfortunately, demand for such certainty of price can be unfair and amount to a punitive penalty because contractors have no control over ground conditions nor the behaviour of the various regulatory limbs and authorities and corporations peculiarly under the influence of the Crown. Ultimately contractors are forced to 
Regulatory Baseline Reporting: The Case for Quantifying Expected Regulatory Costs and Delays in a Baseline Report - Lessons in Crown Unfairness from Australia

price such unknown risks into their bids with little or no mechanisms to mitigate the consequences on their projects.

The increasingly common result of such risk transfer is that contractors either decline to participate in the bidding process or they engage in a combination of pricing the risk and/or cost recovery via claims and litigation once previously immeasurable costs have crystalised. The natural consequence of such conduct is inefficient project delivery, delays, variations, disputes and a declining confidence in the underground works sector by both government and private sectors.

Organisations such as the World Bank, International Federation of Consulting Engineers (FIDIC), the International Tunnelling and Underground Space Association (ITA) and the Swiss Tunnelling Association (SIA) have promoted and adopted engineering focused new forms of risk allocation that recognise and more responsibly allocate risk between the contracting parties. These modern mechanisms are considered likely to result in lower project prices, reduced litigation, and better underground works infrastructure[16][17]

The one common feature of international approaches is that they use standard contracts which are universally understood and tested. Countries such as Australia's approach of developing bespoke and complex contracts, becomes a self-generating risk mitigation industry in its own right.

\section{CASE STUDY - LAW IN AUSTRALIA}

The Crown has obligations within Australia to act fairly when contracting, although those duties are limited.

The Commonwealth and State Governments are subject to Model Litigant Guidelines which codified the common law position with respect to the Government's unique obligations in the context of litigation.

The earliest formulation of the model litigant principle can be found in the 1912 case of Melbourne Steamship Co Ltd v Morehead[18]where Griffith CJ observed that the role of the Crown in litigation is:

The old fashioned, traditional and almost instinctive, standard of fair play to be observed by the Crown in dealing with subjects, which I learned a very long time ago to regard as elementary.

This was considered to be so because the Crown's position as 'the source and fountain of justice.'[19]

Support for this notion and more modern formulations of the principle - seen in Federal Court decision of Hughes Aircraft System International v Airservices Australia[20] where Finn J held that:

There is, I consider much to be said for the view that, having no legitimate private interest in the performance of its functions, a public body...should be required as of course to act fairly towards those with whom it deals at least in so far as this is consistent with its obligation to serve the public interest (or interests) for which it has been created.

The Courts have consistently recognised that the Crown and its agencies must act as a model litigant.[21]

Whilst it is not controversial that the Crown must act as a model litigant, the question of whether it is required to be a model contractor is more complicated given the $19^{\text {th }}$ and $20^{\text {th }}$ century focus on the principles of self-interest and freedom of contract which underpin Australian contract law. 
Since the New South Wales decision in Renard Constructions (ME) Pty Ltd v Minister for Public Works[22] the concept of an implied term of good faith in contracting has begun to take shape and there has been much debate within the Courts and by academics as to whether an implied term of good faith exists within commercial and government contracts. Although any implied term of good faith would apply to all parties to the contract, this is the closest thing to any requirement that the Crown must conduct itself differently in the course of contracting.

The decision of Renard in the New South Wales Court of Appeal decided that when a discretionary right is an explicit term of the contract, the discretionary power involved with triggering the application of such a clause requires such power to be exercised reasonably, not capriciously or for some extraneous purpose.[23] Renard is said to mark the start of the implication of good faith in Australian contract law.

In Alcatel Australia Ltd v Scarcella [24] the Court followed Renard and held that in NSW, a duty of good faith in performing obligations and exercising rights may by implication be imposed upon parties as part of a contract. Later, in Burger King v Hungry Jack's Pty Ltd[25] the Court observed that there appeared to be increasing acceptance that if the terms of good faith and reasonableness are to be implied that they are to be implied as a matter of law.[26]

In Victoria, the Courts have been more circumspect about finding an implied term of good faith in commercial contracts. In Esso Australia Resources Pty Ltd v Southern Pacific Petroleum NL[27]Warren CJ stated:

[I]f a duty of good faith exists, it really means that there is a standard of contractual conduct which should be met. The difficulty is that the standard is nebulous....If good faith is not readily capable of definition then that certainty is undermined...ultimately the interests of certainty in contractual activity should be interfered with only when the relationship between the parties is unbalanced and one party is at a substantial advantage, or is particularly vulnerable... where commercial leviathans are contractually engaged, it is difficult to see that a duty of good faith will arise, leaving aside duties that may arise in a fiduciary relationship.[28]

The High Court of Australia has not ruled decisively on this issue. In Royal Botanic Gardens and Domain Trust $v$ South Sydney City Council[29]the Court recognised the importance of issues concerning the existence and content of an implied obligation or duty of good faith and fair dealing but did not consider it necessary to rule directly on those issues in the case.

The Federal Court on the other hand has implied a term of good faith in a number of cases: see: Hughes Aircraft Systems International v Airservices Australia[30] and Pacific Brands Sport \& Leisure Pty Ltd v Underworks Pty Ltd.[31] Notably, as a result of the decision in Hughes, the Commonwealth Procurement Guidelines include specific guidance on probity considerations.

An analysis of the case law indicates that good faith is about a baseline of standards and overarching principles of fairness and reasonableness. The current procurement policies for both the Commonwealth and State governments reflect some of the types of behaviour which the legal concept of good faith requires.

The Courts have implied a term of good faith in the following circumstances:

- In the conduct of a tender if there is a pre-award contract governing the tender process[32]

- In the conduct of a show cause procedure prior to taking over the works or terminating a contract[33]

- In the exercise of a right generally to terminate[34] 
Regulatory Baseline Reporting: The Case for Quantifying Expected Regulatory Costs and Delays in a Baseline Report - Lessons in Crown Unfairness from Australia

- In fulfilling the obligation arising from a right of pre-emption (that is, a first right of refusal) where a vendor must make a bona fide offer to the party entitled to the right[35]

- In the conduct of dispute resolution, including mediation under an express dispute resolution clause in a contract.[36]

Whilst the law in Australia on this issue is far from settled it is at least established that it is likely that a term of good faith will be implied in most government contracts. The content of such a term was best summarised in the Burger King case in the following terms:

- A duty of good faith both in performing obligations and exercising rights may be implied into the contract

- Implied terms of good faith and fair dealing oblige parties to exercise powers and rights conferred by the agreement in good faith and not for some unrelated or irrelevant purpose

- Obligations of good faith and reasonableness will be readily implied in standard form agreements, especially if there is a general power of termination

- Australian cases make no distinction between reasonableness and good faith

Even though the requirement to act in good faith doesn't only apply to a government party to a contract, and even though it is far less prescriptive than the model litigant guidelines, it still assists in putting companies on a more even footing with government contracting parties. Furthermore, the fact that the government procurement guidelines (both at a Commonwealth and State level) reflect this requirement means that the government may be held more accountable when its conduct falls short of the required standard.

\section{DISCUSSION}

Governments should be held accountable for project risks that compromise the ability of a successful bidder to perform its promises under a contract. While it may be entirely reasonable for a successful bidder to assume a level of regulatory risk, it is entirely unreasonable that this burden to fall entirely on the contractor because it cannot be readily quantified in this commercial environment and is almost entirely within the control and influence of the systems and processes of the Crown. As is the case with sovereign ground risk and GBRs where mistakes about ground condition are presumed to be the burden of the Crown there is also a strong case founded in the concepts of fairness that anticipated regulatory impacts (such as cost and time) should be described and costed in a Regulatory Baseline Report (RBR) at the time of contracting and departures from that Regulatory Baseline Report used to either increase or decrease the liability of the Crown.

There should be a mechanism for Crown accountability for unanticipated cost and delays associated with services relocation (retail and wholesale water, power, gas, sewerage, roads, telecommunications, drainage), third party approvals (planning, environment, transport regulator, fire authorities and other government discretionary processes), changes to applicable standards, betterment, and even inappropriate exercise of project verification mechanisms.

The unfairness is not that any of the above matters are unanticipated, but that, by virtue of the existing contractual arrangements the risks are often unmanageable and unquantifiable at the time of bid, and therefore the Contractor must endure these burdens with little and typically no accountability of government for their abrogation of control over their own authorities and servants. Delivery authorities - no matter how well intentioned or resourced - 
cannot effectively deliver projects for their client (the Crown) when there is no accountability to the Crown for the actions of its other Crown agencies.

The fair apportionment of regulatory risk and ground risk in underground works contracts is fundamental to the Crown achieving the best value for its citizens in the delivery of underground works. With the lack of accountability of the Crown each regulatory discretion becomes a tool for different authorities to achieve non-disclosed objectives. Projects are forced to agree to manifestly inappropriate requirements from government agencies because the cost of delay is entirely born by the Contractor no matter how unmeritorious the demands of the regulatory process. Accountability in the contracts for such conduct, via at the very least the adoption of a Regulatory Baseline Report, would at the very least provide a level of accountability to the Crown for such conduct.

Underground works projects are so large and time consuming that the regulatorily environment under the Crown's control can reasonably be expected to change during the life of the project. By defining an agreed range of regulatory risk, contractors can be penalised for failing to meet specified regulatory targets and the Crown can be held responsible for not delivering the level of regulatory certainty represented during the bidding process.

There are new methods in contracting which seek to mitigate risks for underground works projects more fairly than traditional Australian lump sum, all risk contracts. ITA / FIDICs new Emerald Book is based upon FIDICs highly successful conditions of contract for plant and design build[37]. These are far more mature approaches to contracting than bespoke contracts and an unspoken complete Crown risk transfer contractual practice agenda.

If Regulatory Baseline Reports were adopted in a similar way to Geotechnical Baseline Reports the Crown would assume responsibility for regulatory risks uniquely within its control. This would make the contractor responsible for regulatory matters anticipated at the time of contracting while also creating accountability for the Crown if Crown agencies and processes failed to deliver the necessary approvals or resulted in the imposition of unanticipated costs and delays.

Commercial tensions should be directed at matters within the parties' control. Contractors bring their technical skills to a project and the Crown brings unique ability to manage the regulatory environment. It is time that contractor accountability for the timely delivery of underground works projects to the standard and quality represented at the time of contracting be balanced with Crown accountability for managing the regulatory environment for constructing such projects. A Regulatory Baseline Report (RBR) would set out the allocation of these regulatory risks between the parties.

Given the distress internationally in underground works projects caused by regulatory risks that are peculiarly within the control or influence of the Crown, it is likely that Courts would find in some cases the absolute allocation of regulatory risks by the Crown to the contractors unfair.

\section{CONCLUSIONS}

In the $21^{\text {st }}$ century strong and trusted relationships between the Crown (and those entities over which it has direct or indirect authority and control) and the private sector are often required to deliver the complex and demanding underground works required to support and propel nations into a prosperous $22^{\text {nd }}$ century.

Archaic contractual practices that emerged through the $19^{\text {th }}$ and $20^{\text {th }}$ centuries to transfer sovereign risk and regulatory risks no longer serve nations well because they tend to bring the Crown and the private sector into disrepute and promote hostile claims based project delivery with a focus on litigation and not engineering. 
Regulatory Baseline Reporting: The Case for Quantifying Expected Regulatory Costs and Delays in a Baseline Report - Lessons in Crown Unfairness from Australia

Modern $21^{\text {st }}$ century mechanisms for regulatory risk and ground risk allocation and dispute management - with their focus on engineering and the delivery of timely infrastructure, are a fair and welcome change to the legalistic practices of the past. The adoption of RBRs with the objective of developing a common contractual framework is encouraged. Prudent risk apportionment and modern forms of dispute avoidance should be at the heart of a modern approaches to underground works project delivery.

It is increasingly likely that Courts will construe absolute risk transfer of regulatory disturbances created or effectively under the control of the Crown as unfair and unlawful. In this context it is inevitable that contracting practices must modernise - such changes are long overdue for global prosperity to consolidate and improve the human condition using underground infrastructure as we grow our economies beyond the $21^{\text {st }}$ century.

\section{REFERENCES}

[1] A Ten Point Commitment to the Construction Sector, Government of NSW, June 2018 Point $2, \mathrm{p} 4$

[2] A Ten Point Commitment to the Construction Section, Government of NSW, June 2018 Point $2, \mathrm{p} 4$

[3] ITIG 2012, Code of Practice for Risk Management of Tunnel Works, International Tunnelling Insurance Group

[4] Baulderstone (SA), Hornibook (Qld), Transfield, Leightons, John Holland, Thiess, Civil and Civic, Lend Lease, Fulton Hogan (Australia), Acciona, Salini, CPB

[5] FIDIC Emerald Book, 2019 Edition

[6] Holdsworth, W. S., A History of English Law (2 $2^{\text {nd }}$ Edition) 1937

[7] Statute of Frauds, 1677

[8] Buckridge v Shirley (1671)

[9] Reech v. Kennegal (1748) 1 Ves. sen.123; 27 E.R. 932

[10] The Greek provision describing the notion of good faith is article 281 of the Greek Civil Code

[11] Romilly M.R., in Haywood v Cope (1858) 25 Beav.140

[12] Australia Hotel Co. Limited v Moore (1899) 20 L.R. NSW

[13] See for example: Jackson, R. V., 1977, Australian Economic Development in the $19^{\text {th }}$ Century, p. 152

[14] Dix. A., 2020, Corruption taxes and the cost of major underground infrastructure, Tunnelling Journal Feb/March 2020

[15] Each Crown has the ultimate power to change any law and avoid any contract. This is at the heart of the concept of Sovereignty and the International Law of Nations.

[16] FIDIC Emerald Book, 2019 Edn.

[17] Dix, A. E., 2020, The Renaissance of Fairness in Ground Risk Allocation - The New ITA/FIDIC Emerald Book, International Journal of Civil Engineering and Technology 11(1), 2020, p43-52

[18] (1912) 15 CLR 333, 342

[19] Sebel Products v Commissioner of Customs and Excise [1949] Ch 409, 413

[20] (1997) 76 FCR 151, 196

https://iaeme.com/Home/journal/IJCIET 41 editor@iaeme.com 
[21] Kenny v State of South Australia (1987) 46 SASR 268 at 273; Yong Jun Qin v The Minister for Immigration and Ethnic Affairs (1997) 75 FCR 155

[22] (1992) 26 NSWLR 234

[23] Ibid

[24] (1998) 44 NSWLF 349

[25] [2001] NSWCA 187

[26] Ibid at [164]

[27] [2005] VSCA 228 at [29]

[28] Ibid at [3]-[4]

[29] [2002] HCA 5

[30] (1997) 146 ALR 1

[31] [2005] FCA 2008

[32] Hughes

[33] Renard

[34] Garry Rogers Motors (Aust) Pty Ltd v Subaru (Aust) Pty Ltd (1999) ATPR 41-703; Burger King

[35] Transfield Properties (Kent Street) Pty Ltd v Swift Pty Ltd (1994) 36 NSWLR 321; Beneficial Finance Corp Ltd v Multiplex Constructions Pty Ltd (1995) 36 NSWLR 510

[36] Aiton Australia Pty Ltd v Transfield Pty Ltd (1999) 153 FLR 236

[37] The Yellow Book in turn was published by FIDIC as an update of the FIDIC 1999 Conditions of Contract for Plant and Design-Build (Yellow Book), First Edition. 